\title{
PENINGKATAN KEMAMPUAN BERPIKIR KRITIS MAHASISWA PENDIDIKAN BIOLOGI UMM MELALUI LESSON STUDY
}

(Lesson Study dilakukan oleh kelompok dosen Prodi Pendidikan Biologi UMM, pada matakuliah Mikrotehnik dan Embriologi dengan menerapkan pembelajaran proyek dan Two Stay Three Stray pada mahasiswa Semester VI Angkatan 2011)

\author{
Sri Wahyuni ${ }^{1)}$, Rr. Eko Susetyarini ${ }^{2)}$, Roimil Latifa ${ }^{3)}$ \\ FKIP Universitas Muhammadiyah Malang \\ E-mail ${ }^{1)}$ : swahyuni48@gmail.com \\ E-mail2) : niniek08@gmail.com \\ E-mail ${ }^{3)}$ : roimil.latifa@yahoo.com
}

\begin{abstract}
ABSTRAK
Penelitian ini bertujuan mendiskripsikan peningkatan kemampuan berpikir kritis mahasiswa melalui kegiatan lesson study serta menemukan Best Practices pembelajaran melalui pelaksanaan lesson study. Metode penelitian ini adalah diskriptif dengan menerapkan lesson study dengan langkah Plan-Do-See (4 Siklus). Lesson Study dilakukan oleh kelompok dosen Prodi Pendidikan Biologi UMM, pada matakuliah Mikrotehnik dan Embriologi dengan menerapkan pembelajaran proyek dan Two Stay Three Stray pada mahasiswa Semester VI Angkatan 2011. Subyek penelitian mahasiswa program studi pendidikan biologi sem VI yang berjumlah 30 orang pada tahun ajaran 2013-2014 yang menempuh matakuliah mikroteknik dan embriologi. Parameter kemampuan berfikir kritis meliputi:kejelasan (clarity), tingkat akurasi (accuracy) presisi (precision), relevansi (relevance), logika berpikir yang digunakan (logic), keluasan sudut pandang (breadth) kedalaman berpikir (depth), kejujuran (honesty) tetap, kelengkapan informasi information) dan bagaimana implikasi dari solusi yang dikemukakan (implication). Kesimpulan penelitian ini adalah penerapan pembelajaran proyek pada matakuliah Mikroteknik dapat meningkatkan kemampuan berfikir kritis sebesar 18,5\%. Sedangkan penerapan pembelajaran Two Stay Three Stray pada matakuliah Embriologi dapat meningkatkan berfikir kritis sebesar 15\%. Best practices Kegiatan Lesson Study di Prodi Pendidikan Biologi Universitas Muhammadiyah Malang adalah adanya kekompakan dan semangat kerja tim dosen dan mahasiswa dalam pemecahan masalah pada matakuliah Mikroteknik dan Embriologi, serta adanya perubahan paradigma pada diri dosen dari teaching menjadi learning.
\end{abstract}

Kata kunci: Lesson study, Kemampuan berfikir kritis, (Pembelajaran Proyek, Two Stay-Three Stray)

\begin{abstract}
The research is purposed to describe the improvement on the critical thinking skill of the students through lesson study and to find the best practices through the implementation of the lesson study. The method used in the research is descriptive by implementing the lesson study with plan-do-see stages (4 cycles). The lesson study is conducted by lecturers of Biology Education Department UMM on Microtechnic and Embriology subjects by using project based learning and Two Stay Three Stray method on 6th semester students year 2011. The subject of the research is 30 6th semester students of Biology Education Department on year 2013-2014 currently taking Microtechnic and Embriology subjects. The parameter of the critical thinking includes: clarity, accuracy, precicion, relevance, logic, breadth of perspective, depth of thinking, honesty, information complexity, and social implication of the solution. The conclusion of this research is $18,5 \%$
\end{abstract}


improvement on critical thinking in the Microtechnic subject by the implementation of project based method and 15\% improvement on critical thinking by the implementation of Two Stay Three Stray method in Embriology subject. The best practices on the lesson study in Biology Education Department is the togetherness and teamwork spirit of the lecturers and students in solving the problem in Microtechnic and Embriology subjects, and the paradigm shift within the lecturer's identity from teaching-based to learning-based.

Keywords: Lesson study, critical thinking ability, project based learning, Two Stay Three Stray method

\section{PENDAHULUAN}

Mahasiswa merupakan bagian dari sumber daya alam yang mempunyai sumbangan dalam memajukan bangsa. Mahasiswa seharusnya mempunyai kepekaan dan kepedulian terhadap kondisi di sekelilingnya. Sikap peka dan peduli mahasiswa terhadap kondisi di sekitarnya perlu ditumbuhkan, Mahasiswa perlu dilatih agar mempunyai kesadaran untuk menggali informasi, ilmu pengetahuan dan membekali diri dengan kapasitas keilmuan yang tinggi sehingga mahasiswa mempunyai kemampuan untuk berpikir kritis (Fitri, 2011).

Menurut Paul \& Elder (2005), berpikir kritis merupakan cara bagi seseorang untuk meningkatkan kualitas dari hasil pemikiran menggunakan teknik sistematis cara berpikir dan menghasilkan daya pikir intelektual. Kriteria dalam proses berpikir kritis ini adalah kejelasan (clarity), tingkat akurasi (accuracy), tingkat kepresisian (precision), relevansi (relevance), logika berpikir yang digunakan (logic), keluasan sudut pandang (breadth), kedalaman berpikir (depth), kejujuran (honesty), kelengkapan informasi (information) dan bagaimana implikasi dari solusi yang dikemukakan (implication), maka diperlukan cara membelajarkan suatu mata kuliah sehingga terjadi peningkatan kemampuan berpikir kritis mahasiswa.

Upaya yang ditempuh untuk meningkatkan kemampuan berfikir kritis diantaranya dapat dilakukan melalui penerapan metode proyek dan Two Stay Three Stray. Pada matakuliah Mikroteknik, perkuliahan dengan pembelajaran proyek mahasiswa akan belajar dalam tim kolaboratif, ketika mahasiswa belajar dalam tim mahasiswa akan menemukan keterampilan merencanakan, berorganisasi, negoisasi, dan membuat konsensus tentang hal-hal yang akan dikerjakan dalam pembuatan preparat histologi, disamping itu mahasiswa akan berkonsultasi dengan dengan dosen/ instruktur atau tim ahli untuk mengkomunikasikan perkembangan kegiatannya. Menurut Thomas et al. (1999) dan Thomas (2000) pembelajaran merupakan tugas-tugas komplek, yang didasarkan pada pertanyaan-pertanyaan yang menantang atau permasalahan, yang melibatkan para siswa di dalam desain, pemecahan masalah, pengambilan keputusan, atau aktivitas investigasi; memberi peluang para mahasiswa untuk bekerja secara otonomi dengan periode waktu tertentu; dan akhirnya menghasilkan produk-produk yang nyata. Menurut Purworini (2006), Pembelajaran proyek dapat meningkatkan hasil belajar siswa, meningkatkan aktivitas dan keterlibatan siswa dalam pembelajaran, menumbuhkan kreativitas dan karya siswa, lebih menyenangkan, bermanfaat serta lebih bermakna .

Penelitian Rais (2010) pada 30 orang mahasiswa semester $\mathrm{V}$ jurusan Teknik Mesin UNM, dengan penerapan pembelajaran proyek menunjukkan bahwa rata-rata skor pretest adalah 62,3 dan skor posttest adalah sebesar 81,58. Perbedaan nilai rata-rata skor ini menunjukkan peningkatan yang cukup 
signifikan dalam hal prestasi akademik atau hasil belajar mahasiswa. Menurut Corebima (2011) pembelajaran proyek merupakan pembelajaran dirancang agar pebelajar dapat melakukan penyelidikan atau tugas lain secara mandiri dalam pola proyek. Pada pembelajaran semacam ini para pebelajar memiliki keleluasaan merancang dan melaksanakan rencana pembelajarannya. Dengan demikian para pebelajar terus menerus dituntut untuk berpikir tingkat tinggi. Sehubungan dengan itu Karyana (2013) menjelaskan bahwa mengembangkan kemampuan berpikir itu tidak dapat dilakukan hanya dengan melalui metode ceramah atau penjelasan saja, akan tetapi harus banyak melatih dan mempraktekkan keterampilan berpikir melalui pembelajaranpembelajaran aktif misalnya pembelajaran proyek.

Pembelajaran berbasis proyek merupakan pembelajaran yang berpusat pada proses, relatif berjangka waktu, berfokus pada masalah, unit pembelajaran bermakna dengan memadukan konsepkonsep dari sejumlah komponen baik itu pengetahuan, disiplin ilmu atau lapangan. Pada pembelajaran berbasis proyek kegiatan pembelajarannya berlangsung secara kolaboratif dalam kelompok yang heterogen. Mengingat hakikat kerja proyek adalah kolaboratif, maka pengembangan keterampilan belajar berlangsung diantara mahasiswa. Pada pembelajaran berbasis proyek kekuatan individu dan cara belajar yang diacu dapat memperkuat kerja tim sebagai suatu keseluruhan. Menurut Mahanal (2009) pembelajaran Pembelajaran proyek secara umum memiliki pedoman langkah: Planning (perencanaan), Creating (mencipta atau implementasi), dan Processing (pengolahan). Kemendikbud,
(2013) langkah-langkah pembelajaran proyek meliputi 1) penentuan pertanyaan mendasar 2) menyusun perencanaan proyek 3) menyusun jadwal 4) monitoring 5). menguji hasil 6). evaluasi pengalaman.

Pada mata kuliah Embriologi, proses belajar mengajar menggunakan metode two stay three stray. Menurut Lie (2002) metode pembelajaran TS-TS, mahasiswa belajar memecahkan masalah bersama anggota kelompok, kemudian dua mahasiswa dari kelompok tersebut bertukar informasi kedua anggota kelompok lain yang tinggal. Mahasiswa dituntut untuk memiliki tanggungjawab dan aktif dalam setiap kegiatan pembelajaran. Penyampaikan materi dikaitkan dengan kehidupan sehari-hari atau hasil penelitian sehingga mahasiswa mudah memahami karena membumi dan menumbuhkan nilainilai karakter sesuai kepribadian.

Beberapa temuan pada proses perkuliahan adalah kurang menekankan pada aspek kognitif yang tinggi, seperti ketajaman daya analisis dan evaluasi, dan berkembangnya kreativitas, sehingga mahasiswa selama mengikuti perkuliahan relatif pasif, mereka datang kuliah tanpa bekal materi yang cukup. Beberapa temuan di lapang menunjukkan bahwa ranah kognitif level tinggi dan ranah afektif masih agak terbengkelaikan, padahal ranah ini penting dalam masyarakat ilmiah untuk kehidupan mahasiswa maupun di dunia kerja.

Untuk perbaikan perkuliahan, dosen yang tergabung dalam satu rumpun ilmu melakukan perencanaan pembelajaran bersama-sama, mendiskusikan kompetensi (kognitif, afektif dan psikomotorik) yang harus dimiliki oleh mahasiswa, materi kuliah yang perlu dipelajari mahasiswa untuk memiliki kompetensi tersebut, mendiskusikan bagaimana merencanakan penyajian 
materi itu kepada mahasiswa, mempraktekkan rencana yang telah disusun dan dosen lain mengobservasinya, melakukan refleksi kegiatan pembelajaran bersama-sama, apakah dengan penyajian yang direncanakan tersebut mahasiswa telah mencapai kompetensi yang diinginkan. Kegiatan tersebut dinamakan lesson study. Menurut Hendayana S, (2007), lesson study yaitu suatu model pembinaan profesi pendidik melalui pengkajian pembelajaran secara kolaboratif dan berkelanjutan berlandaskan prinsip-prinsip kolegialitas dan mutual learning untuk membangun komunitas belajar. Sedangkan menurut Kemendiknas, (2013) lesson Study merupakan kegiatan pengkajian pembelajaran yang dilakukan oleh sekelompok guru/dosen secara kolaboratif dan berkelanjutan untuk menguji dan meningkatkan keefektifan pembelajaran.

Lesson Study merupakan komunitas belajar (learning society) yang secara konsisten dan sistematis melakukan perbaikan diri, pada tataran individual maupun manajerial. Pembelajaran secara kolaboratif dan berkesinambungan merencanakan, melaksanakan, mengobservasi dan melaporkan hasil pembelajaran (Supriatna, 2012).

Kegiatan LS, pengkajian pembelajaran yang dilakukan oleh sekelompok guru/ dosen secara kolaboratif dan berkelanjutan untuk menguji dan meningkatkan keefektifan pembelajaran (Pelaksanaan LS meliputi beberapa tahap, yaitu perencanaan (plan), pelaksanaan (do) dan refleksi (see), kegiatan ini dilakukan oleh sekelompok dosen. LS dapat dibelajarkan pada mahasiswa (calon guru), karena LS dilakukan secara berkala dan berkelanjutan dalam rangka meningkatkan kompetensi dan keprofesionalan guru. (Ibrohim, 2011). Kegiatan LS dalam pembelajaran, selain sebagai upaya mengaktifkan mahasiswa, berdampak pada dosen dapat melakukan review terhadap kinerja dosen dan pengembangan kemampuan akademik mahasiswa serta menumbuhkan sikap berhati-hati dan bertanggung jawab dalam belajar. LS akan diobservasi dan direfleksi bersama-sama oleh mahasiswa, observer maupun oleh dosen observer.

\section{METODE}

Penelitian ini merupakan penelitian deskriptif dengan mengimplementasikan lesson study. Adapun subyek penelitian adalah mahasiswa Program Studi Pendidikan Biologi Angkatan 2011 Semester Enam Kelas A yang menempuh mata kuliah Embriologi dan Reproduksi Hewan berjumlah 30 orang. Pengimplementasian lesson Study ini dilakukan dalam 4 kali putaran yang terdiri dari 2 kali putaran untuk MK. Mikroteknik dan 2 kali putaran untuk MK. Embriologi. Masing masing putaran terdiri dari 3 Tahapan yaitu: (1) tahap perencanaan (plan), (2) Tahap pelaksanaan (do), serta (3) tahap refleksi (see).

Sintaks pembelajaran proyek meliputi: 1) penentuan pertanyaan mendasar 2) menyusun perencanaan proyek 3) menyusun jadwal 4) monitoring 5) menguji hasil 6) evaluasi pengalaman.

Kemampuan berpikir kritis yang diamati adalah kejelasan (clarity), tingkat akurasi (accuracy), tingkat kepresisian (precision), relevansi (relevance), logika berpikir yang digunakan (logic), keluasan sudut pandang (breadth), kedalaman berpikir (depth), kejujuran (honesty), kelengkapan informasi (information) dan bagaimana implikasi dari solusi yang dikemukakan (implication).

Instrument pengumpulan data menggunakan Lembar Kerja/Lembar pengamatan dan dokumentasi. Data 
dianalisis dengan analisis diskriptif dan prosentase yang digunakan untuk mendiskripsikan tentang kemampuan berfikir kritis mahasiswa.

\section{HASIL DAN PEMBAHASAN}

Kegiatan Plan, do, see Mata Kuliah Mikroteknik

\section{Pelaksanaan Kegiatan Perencanaan (Plan)}

Dalam tahap perencanaan, para pengajar yang tergabung dalam lesson study berkolaborasi untuk menyusun RPP yang mencerminkan pembelajaran yang berpusat pada mahasiswa. Perencanaan diawali dengan kegiatan menganalisis kebutuhan dan permasalahan yang dihadapi dalam pembelajaran, seperti mengembangkan kompetensi dasar menjadi kegiatan pembelajaran aktif, cara membelajarkan mahasiswa, mensiasati kekurangan fasilitas dan sarana belajar, dan sebagainya, sehingga dapat ketahui berbagai kondisi nyata yang akan digunakan untuk kepentingan pembelajaran. Selanjutnya, secara bersamasama pula dicarikan solusi untuk memecahkan segala permasalahan ditemukan. Kesimpulan dari hasil analisis kebutuhan dan permasalahan menjadi bagian yang harus dipertimbangkan dalam penyusunan RPP, sehingga RPP menjadi sebuah perencanaan yang benarbenar sangat matang, yang didalamnya sanggup mengantisipasi segala kemungkinan yang akan terjadi selama pelaksanaan pembelajaran berlangsung, baik pada tahap awal, tahap inti sampai dengan tahap akhir pembelajaran.

\section{Pelaksanaan Kegiatan (Do)}

Pada tahapan yang kedua, terdapat dua kegiatan utama yaitu: (1) kegiatan pelaksanaan pembelajaran yang dilakukan oleh salah seorang Dosen yang disepakati atau atas permintaan sendiri untuk mempraktikkan RPP yang telah disusun bersama, dan (2) kegiatan pengamatan atau observasi yang dilakukan oleh anggota lesson study yang lainnya yang bertindak sebagai pengamat/observer).

Pertemuan 1 Kamis, 15 Mei 2014 Langkah Metode Proyek Matakuliah Mikroteknik

1) Penentuan Pertanyaan Mendasar (Start With the Essential Question). Pembelajaran dimulai dengan pertanyaan esensial, yaitu pertanyaan yang dapat memberi penugasan kepada mahasiswa dalam melakukan suatu aktivitas. mengambil topik yang sesuai dengan realitas dunia nyata dan dimulai dengan sebuah investigasi mendalam. Dosen berusaha agar topik yang diangkat relevan untuk para mahasiswa. Kegiatan pembelajaran sebagai berikut: Masing-masing kelompok terlebih dahulu mempelajari atau mengkaji literatur tentang metode mikroteknik). yang telah dibawa oleh setiap anggota kelompok. Dengan kegiatan tersebut akan muncul pertanyaan esensial, yaitu pertanyaan yang dapat memberi ide kepada mahasiswa dalam melakukan suatu aktivitas terkait tugas yang diberikan dosen. Mahasiswa mendiskusikan perbedaan handout, buku, dan modul. Diskusi didasarkan pada contoh-contoh yang telah dibawa oleh mahasiswa. Mahasiswa mempresentasikan hasil kerjanya secara bergantian, Mahasiswa lain memberikan tanggapan. Dosen memberi penguatan dengan menunjukkan acuan pembuatan berbagai metode mikroteknik terutama whole mount, gosok, pollen, maserasi, yang akan dibuat oleh mahasiswa. 
2) Mendesain Perencanaan Proyek (Design a Plan for the Project).

Perencanaan dilakukan secara kolaboratif antara pengajar dan peserta didik. Dengan pemikiran peserta didik diharapkan akan merasa "memiliki" atas proyek tersebut. Perencanaan berisi tentang aturan main, pemilihan aktivitas yang dapat mendukung dalam menjawab pertanyaan esensial, dengan cara mengintegrasikan berbagai subjek yang mungkin, serta mengetahui alat dan bahan yang dapat diakses untuk membantu penyelesaian proyek.

3) Menyusun Jadwal (Create a Schedule)

Dosen dan mahasiswa secara kolaboratif menyusun jadwal aktivitas dalam menyelesaikan proyek. Aktivitas pada tahap ini antara lain: (1) membuat timeline untuk menyelesaikan proyek, (2) membuat deadline penyelesaian proyek, (3) mendorong mahasiswa agar merencanakan cara yang baru, (4) membimbing mahasiswa ketika mereka membuat cara yang tidak berhubungan dengan proyek, dan (5) meminta peserta didik untuk membuat penjelasan (alasan) tentang pemilihan suatu cara. Selanjutnya dosen memberikan umpan balik terhadap proses dan hasil pembelajaran dengan menanyakan apakah masih ada yang mengalami kesulitan atau masih adakah konsep yang belum dipahami oleh mahasiswa.

\section{Refleksi}

Setelah pelaksanaan pada putaran pertama, pada waktu yang sama setelah pembelajaran diakhiri dilakukan refleksi. Refleksi bertujuan untuk melihat keterlaksanaan pembelajaran yang telah dilaksanakan. Refleksi dilakukan oleh dosen model dan semua observer. Salah seorang observer (Dr. Rr. Eko Susetyarini, M.Si) ditunjuk sebagai moderator serta notulen. Hasil dari refleksi ini digunakan untuk perbaikan pembelajaran pada putaran selanjutnya. Berikut hasil refleksi putaran I:

1. Ada beberapa mahasiswa yang tidak memperhatikan, tidak memahami materi

2. Beberapa mahasiswa datang terlambat

3. Tidak ada tanda pengenal yang digunakan mahasiswa sehingga observer kesulitan untuk mengamati aktivitas mahasiswa.

4. Dalam kegiatan pengamatan, terlihat mahasiswa kebingungan

5. Waktu yang digunakan untuk pengamatan tidak efisien.

Upaya perbaikan pembelajaran pada putaran selanjutnya (putaran II) yaitu sebagai berikut:

1. Softcopy materi dapat diberikan kepada ketua kelompok masingmasing sesuai dengan pembagian materi yang sudah ditetapkan sebelumnya.

2. Dengan melihat keaktifan mahasiswa pada putaran I maka pengelompokkan mahasiswa dapat dilakukan berdasarkan kemampuan tinggi rendah siswa yang dilihat dari keaktifan siswa pada pelaksanaan putaran I tsb.

3. Untuk memanfaatkan waktu agar lebih efisien maka cara kerja lebih tepat dijelaskan terlebih dahulu oleh dosen model sebelum kegiatan pengamatan dimulai.

4. Agar tidak terlambat disampaikan ada kuis pemahaman atau pretest seelum pelajaran berikutnya di mulai (kegiatan awal)

5. Semua mahasiswa diwajibkan membawa tanda pengenal yang seragam satu kelas. 
Pertemuan 2 : Kamis 22 April 2014

Langkah -langkah utama yang dilakukan adalah :

Memonitor peserta didik dan kemajuan proyek (Monitor the Students and the Progress of the Project)

Dosen bertanggungjawab untuk melakukan monitor terhadap aktivitas peserta didik selama menyelesaikan proyek. Monitoring dilakukan dengan cara menfasilitasi peserta didik pada setiap Proses. Dengan kata lain dosen berperan menjadi mentor bagi aktivitas peserta didik. Agar mempermudah proses monitoring, dibuat sebuah rubrik yang dapat merekam keseluruhan aktivitas yang penting. Selanjutnya dosen memberi komentar atas pekerjaan mahasiswa. Mahasiswa membuat laporan kemajuan yang dipantau oleh dosen.

Pertemuan 3 : Kamis 29 April 2014

Langkah-langkah kegiatan utama yang dilakukan adalah melanjutkan monitoring proyek. Kegiatan yang dilakukan pada pertemuan ini melanjutkan pemantauan Pertemuan ke tiga, diawali dengan pameran hasil tugas rumah, untuk saling dikoreksi. menggunakan rubrik yang dapat merekam keseluruhan aktivitas yang penting. Dosen bertanggungjawab untuk melakukan monitor terhadap aktivitas peserta didik selama menyelesaikan proyek. Monitoring dilakukan dengan cara menfasilitasi peserta didik pada setiap Proses. Dengan kata lain Dosen berperan menjadi mentor bagi aktivitas peserta didik. Agar mempermudah proses monitoring, dibuat sebuah rubrik yang dapat merekam keseluruhan aktivitas yang penting. Selanjutnya dosen memberi komentar atas pekerjaan mahasiswa. Mahasiswa membuat laporan kemajuan yang dipantau oleh dosen.
Pertemuan 4 : Kamis 12 Juni 2014 (Siklus ke IV LS)

\section{Perencanaan (Plan)}

Berdasarkan hasil refleksi putaran I, untuk mengantisipasi kelebihan waktu, dan masih kurangnya mahasiswa yang memahami materi, maka Tim LS menyusun rencana dengan membuat materi dalam bentuk hand out. Tim LS juga menyiapkan RPP tahap 2 dan menyusun lembar evaluasi pada akhir pembelajaran.

\section{Pelaksanaan (Do)}

Melanjutkan langkah kegiatan metode proyek putaran I, Langkah kegiatan yang dilakukan adalah :

a) Menguji Hasil (Assess the Outcome) Penilaian dilakukan untuk membantu dosen dalam mengukur ketercapaian standar, berperan dalam mengevaluasi kemajuan masing-masing peserta didik, memberi umpan balik tentang tingkat pemahaman yang sudah dicapai peserta didik, membantu pengajar dalam menyusun strategi pembelajaran berikutnya. Kegiatan pembelajarannya adalah: mahasiswa duduk sesuai dengan kelompok masing-masing, saling berhadapan sesuai dengan denah yang telah dibuat oleh dosen. Setiap kelompok secara bergiliran diberikan waktu untuk mempresentasikan hasil proyek atau produk. Dosen dan kelompok lain dapat memberikan pertanyaan, kritik dan masukan terkait produk yang dihasilkan. Pada tahap ini dosen dapat mengukur ketercapaian standar, mengevaluasi kemajuan masingmasing peserta didik, dan memberi umpan balik tentang tingkat pemahaman yang sudah dicapai peserta didik. 
b) Mengevaluasi Pengalaman (Evaluate the Experience)

Pada akhir proses pembelajaran, pengajar dan peserta didik melakukan refleksi terhadap aktivitas dan hasil proyek yang sudah dijalankan. Proses refleksi dilakukan baik secara individu maupun kelompok. Pada tahap ini peserta didik diminta untuk mengungkapkan perasaan dan pengalamannya selama menyelesaikan proyek. Pengalaman ini akan menjadi masukan berharga dalam membuat proyek berikutnya. Kegiatan evaluasi pengalaman juga akan dimaksimalkan dengan cara menilai jurnal belajar yang telah mereka buat. Setelah melakukan kegiatan evaluasi pengalaman maka dosen meminta mahasiswa untuk menata ulang tempat duduk (semua mahasiswa menghadap ke depan dan mengatur jarak tempat duduk). Mahasiswa akan mengerjakan kuis secara individual. Mahasiswa tidak diperbolehkan saling membantu dalam mengerjakan kuis. Setiap mahasiswa bertanggung jawab secara individual untuk memahami materi yang telah diperoleh dalam pembelajaran. Setelah semua mahasiswa mengumpulkan jawaban kuis/tes maka dosen mengumumkan kelompok yang terbaik (dari segi desain perencanaan proyek, kekompakan tim, kualitas produk maupun dari segi keaktifan. Dosen lalu memberikan penghargaan.

\section{Refleksi}

Refleksi pada Pelaksanaan LS Siklus IV sudah berjalan sesuai yang diharapkan dari perbaikan pada putaran I. Semua indikator kemampuan berpikir kritis mengalami peningkatan sesuai target awal pelaksanaan LS. Untuk persentase peningkatan kemampuan berpikir kritis dari pelaksanaan putaran I, IV, mata kuliah mikroteknik dapat dilihat pada Tabel I.

Tabel I. Peningkatan Kemampuan Berpikir Kritis Pada Putaran I dan IV Matakuliah Mikroteknik

\begin{tabular}{clccc}
\hline No & Indikator Kemampuan Berpikir Kritis & $\%(\mathrm{I})$ & $\%$ (IV) & P (\%) \\
\hline 1 & Kejelasan & 50 & 75 & 25 \\
2 & Tingkat akurasi & 40 & 65 & 25 \\
3 & Tingkat kepresisian & 40 & 75 & 35 \\
4 & Relevansi & 45 & 60 & 15 \\
5 & Logika berpikir yang digunakan & 50 & 67,5 & 17,5 \\
6 & Keluasan sudut pandang & 50 & 77,5 & 27,5 \\
7 & Kedalaman berpikir & 60 & 67,5 & 17,5 \\
8 & Kejujuran & 70 & 72,5 & 2,5 \\
9 & Kelengkapan informasi & 60 & 72,5 & 12,5 \\
10 & Implikasi dari solusi yang dikemukakan & 70 & 82,5 & 12,5 \\
\hline TOTAL & & & & 185 \\
RERATA & & & & 18,5 \\
\hline
\end{tabular}

Marzano (1994) mengungkapkan bahwa habits of mind dibagi dalam tiga kategorl: self regulated thinking, critical thinking dan creative thinking. Critical Thinking (berfikir kritis) terdiri dari: Bersikap akurat dan mencari akurasi, jelas dan mencari kejelasan, bersikap terbuka, menahan diri dari sifat impulsif. mampu menempatkan diri ketika ada jaminan, bersikap sensitif dan tahu kemampuan pengetahuan temannya. Kemampuan berpikir kritis dapat diamati : kejelasan (clarity), tingkat akurasi (accuracy), tingkat kepresisian (precision), relevansi (relevance), logika berpikir yang digunakan (logic), keluasan sudut pandang (breadth), 
kedalaman berpikir (depth), kejujuran (honesty), kelengkapan informasi (information) dan bagaimana implikasi dari solusi yang dikemukakan (implication).

\section{Kegiatan Plan, do, see Mata Kuliah Embriologi}

Lesson Study Putaran II :

\section{Perencanaan (Plan)}

Tim LS menyusun rencana pembelajaran (RPP) dengan model pembelajaran langsung, menyusun Lembar Kerja Mahasiswa, menyiapkan media pembelajaran, Menyiapkan materi pembelajaran, menyiapkan instrumen penilaian dan menyiapkan lembar observasi kegiatan pembelajaran. Pengelompokkan mahasiswa pada putaran I yaitu berdasarkan nomor. Materi perkuliahan diberikan kepada koordinator matakuliah beberapa hari sebelum tahap pelaksanaan (Do). Hal itu dimaksudkan agar mahasiswa lain dapat memperanyak bahan tersebut kepada koordinator mata kuliah. Metode yang digunakan adalah metode TS-TS. Materi yang akan dibahas adalah kulitas sel gamet (jantan dan betina) dari video hasil penelitian.

\section{Pelaksanaan Kegiatan (Do)}

Dosen model memasuki kelas bersama-sama dengan observer. Masingmasing observer membawa lembar observasi untuk diisi sebagai bahan refleksi setelah tahap pelaksanaan (Do). Tahap pelaksanaan pada putaran pertama ini meliputi langkah-langkah yaitu: (1) mahasiswa membentuk kelompok sesuai dengan pengamatan dari foto atau video tentang sel gamet jantan (spermatozoa) dan betina (ovum) yang telah ditugaskan Mahasiswa berkelompok sesuai kelompok, yaitu epidermis, uterus, ovum, oviduct dan vas deferent, (2) pengelompokan ini didasarkan pada metode yang digunakan yaitu metode TS-TS. (3) mahasiswa melakukan pengamatan sesuai tugas yang telah ditentukan. (4) mengisi lembar pengamatan yang telah disediakan, (5) mendiskusikan permasalahan yang diajukan, (6) mahasiswa menuliskan hasil diskusi di kerta yang telah disediakan, (7). Mahasiswa memajang pekerjaan di tempat yang telah ditentukan,(8) 2 dari anggota kelompok menjelaskan dari hasil pekerjaan yang telah dibuat, anggota yang lain berkomentar ke kelompok, (9) mengamati kemampuan berpikir kritis, yaitu kejelasan (clarity), tingkat akurasi (accuracy), tingkat kepresisian (precision), relevansi (relevance), logika berpikir yang digunakan (logic), keluasan sudut pandang (breadth), kedalaman berpikir (depth), kejujuran (honesty), kelengkapan informasi (information) dan bagaimana implikasi dari solusi yang dikemukakan (implication), (11) memilih kelompok yang mendapatkan komentar terbaik dan komentar terjelek untuk mempresentasikan hasil diskusi, (12) melakukan penguatan terhadap hasil diskusi yang dipresentasikan oleh mahasiswa, (13) menyimpulkan dari hasil kerja mahasiswa, (10) menyampaikan tindak lanjut untuk pertemuan berikut.

\section{Implementasi (Open class) dan Observasi}

Aktivitas yang menunjukkan kemampuan berpikir kritis mahasiswa pada putaran kedua dapat dilihat pada Tabel 2.

\section{Refleksi}

Setelah pelaksanaan pada putaran pertama, pada waktu yang sama setelah pembelajaran diakhiri dilakukan refleksi. Refleksi bertujuan untuk melihat keterlaksanaan pembelajaran yang telah dilaksanakan. Refleksi dilakukan oleh dosen model dan semua observer. Salah seorang observer ditunjuk sebagai moderator serta notulen. Hasil dari refleksi 
ini digunakan untuk perbaikan pembelajaran pada putaran selanjutnya. Berikut hasil refleksi putaran II:

1. Ada beberapa mahasiswa yang tidak memiliki materi yang sudah dicopykan oleh koordinator, hal ini mengakibatkan pelaksanaan pembelajaran tidak optimal. LKM belum diberikan sebelumnya sehingga mahasiswa masih kebingungan, seharusnya semua maha-siswa wajib memiliki bahan/ materi yang sudah diberikan oleh dosen. Mahasiswa belum membaca literartur yang sudah ditetapkan. Ada seorang mahasiswa yang mengantuk pada saat diskusi.

2. Tidak ada tanda pengenal yang digunakan mahasiswa sehingga observer kesulitan untuk mengamati aktivitas mahasiswa.

3. Saat kegiatan pengamatan, terlihat mahasiswa kebingungan, sehingga mengakibatkan waktu yang tersedia tidak efisien. Hal tersebut juga dikarenakan mahasiswa yang angkatan bawah belum paham kegiatan yang akan diamati atau materi.

4. Waktu yang digunakan untuk pengamatan tidak efisien.

5. Pengaturan tempat duduk kelompok perlu diperbaiki

Upaya perbaikan pembelajaran pada putaran selanjutnya (putaran III) yaitu sebagai berikut:

1. Pengelompokkan dapat di lakukan berdasarkan kemampuan tinggi rendah siswa yang dilihat dari keaktifan siswa pada pelaksanaan putaran II.

2. Softcopy materi dan LKM dapat diberikan kepada ketua kelompok masing-masing sesuai dengan pembagian materi yang sudah ditetapkan sebelumnya.

3. Untuk memanfaatkan waktu agar lebih efisien maka cara kerja lebih tepat dijelaskan terlebih dahulu oleh dosen model sebelum kegiatan pengamatan dimulai.

4. Semua mahasiswa diwajibkan membawa tanda pengenal yang seragam satu kelas.

5. Pemanfaatan waktu agar lebih efisien, maka media yang digunakan untuk pengamatan disesuaikan dengan metode.

\section{Lesson Study Putaran III}

\section{Perencanaan (Plan) (proses fertilisasi)}

Berdasarkan hasil refleksi putaran II, untuk mengantisipasi kelebihan waktu, dan masih kurangnya mahasiswa yang memahami materi, maka Tim LS menyusun rencana dengan membuat materi dalam bentuk hand out. Adapun media pembelajaran yang digunakan adalah powerpoint dan tes kehamilan atau kesuburan. Materi yang diajarkan adalah sistem kontrol hormonal. Metode yang digunakan adalah Two Stay-Tree Stray. Tim LS juga menyiapkan lembar evaluasi pada akhir pembelajaran.

\section{Pelaksanaan (do)}

Tahap pelaksanaan pada putaran III ini meliputi langkah-langkah yaitu: (1) mempelajari materi yang akan dipelajari secara mandiri, (2) membentuk kelompok dengan bervariasi anggotanya dari angkatan 2011, (3) mahasiswa membentuk kelompok sesuai dengan pengamatan dari foto atau video tentang proses fertilisasi yang telah ditugaskan Mahasiswa berkelompok sesuai kelompok, yaitu epidermis, uterus, ovum, oviduct dan vas deferent, (4) mencari literatur lain selain yang diberikan dosen, (5) melakukan pengamatan tentang proses fertilisasi, (6) berdiskusi dengan kelompok, (7) menuliskan hasil diskusi kelompok di 
kertas plano, (8) memajang hasil diskusi pada tempat yang disediakan, (9) menanggapi dan bertanya saat bertamu ke kelompok lain, (10) berdiskusi dari hasi pengamatan pada saat bertamu, (11) menunjuk kelompok yang mendapatkan komentar baik terbanyak, dan komentar baik tersedikit, (12) melakukan pengamatan kemampuan berpikir kritis, (12) melakukan penguatan dari hasil diskusi yang disampaikan oleh mahasiswa, (13) memberi penghargaan pada kelompok yang mendapatkan poin baik terbanyak, (14) melakukan kuis, (15) memberikan tugas untuk materi selanjutnya.

\section{Implementasi (Open class) dan Observasi}

Aktivitas yang menunjukkan adanya kemampuan berpikir mahasiswa pada putaran ke II dan ke III dapat dilihat pada Tabel 2.

Tabel 2. Peningkatan Kemampuan Berpikir Kritis Pada Putaran II dan III Mata Kuliah Embriologi Hewan

\begin{tabular}{clcrl}
\hline No & Indikator Kemampuan Berpikir Kritis & $\mathbf{\%}(\mathbf{I I})$ & $\mathbf{\%}(\mathbf{I I I})$ & $\mathbf{P ~ ( \% )}$ \\
\hline 1 & Kejelasan & 50 & 62,5 & 12,5 \\
2 & Tingkat akurasi & 75 & 87,5 & 12,5 \\
3 & Tingkat kepresisian & 50 & 62,5 & 12,5 \\
4 & Relevansi & 60 & 75 & 15 \\
5 & Logika berpikir yang digunakan & 50 & 67,5 & 17,5 \\
6 & Keluasan sudut pandang & 50 & 87,5 & 37,5 \\
7 & Kedalaman berpikir & 50 & 67,5 & 17,5 \\
8 & Kejujuran & 87,5 & 87,5 & 0,0 \\
9 & Kelengkapan informasi & 62,5 & 75 & 12,5 \\
10 & Implikasi dari solusi yang dikemukakan & 50 & 62,5 & 12,5 \\
\hline TOTAL & & & & 150 \\
RERATA & & & & 15 \\
\hline
\end{tabular}

Menurut Lie (2002), pembelajaran kooperatif dengan metode Two Stay Two Stray dengan tahapan penyiapan dan system penilaian, desain pembelajaran, menyiapkan tugas siswa dan membagi mahasiswa menjadi beberapa kelompok dengan masing-masing kelompok terdiri 3, 4 dan 5 mahasiswa. Setiap anggota kelompok harus heterogen dalam hal prestasi akademis siswa maupun jenis kelamin, penjelasan dosen, pengerjaan kelompok oleh mahasiswa dan evaluasi pembelajaran. Kelebihan metode two stay two stray yaitu belajar mahasiswa lebih bermakna, lebih berorientasi pada keaktifan berpikir mahasiswa, meningkatkan motivasi dan hasil belajar mahasiswa, memberikan kesempatan terhadap mahasiswa untuk menentukan konsep sendiri dengan cara memecahkan masalah, memberikan kesempatan kepada mahasiswa untuk menciptakan kreatifitas dalam melakukan komunikasi dengan teman sekelompoknya, membiasakan mahasiswa untuk bersikap terbuka terhadap teman, meningkatkan motivasi belajar mahasiswa (Anonim, 2013)

Dosen menggunakan metode ceramah interaktif untuk memberi motivasi kepada mahasiswa, menyampaikan konsep-konsep penting yang dipelajari sehingga ada hubungan yang jelas antara materi yang dijelaskan dengan pengamatan yang dilakukan mahasiswa.

Dosen membagikan tugas pengamatan kepada setiap kelompok sebagai bahan diskusi. Setiap kelompok memperoleh tugas diskusi yang sama. 


\section{Refleksi}

Hasil refleksi pada putaran ketiga menunjukkan adanya peningkatan aktivitas belajar mahasiswa dalam berpikir kritis tentang pengamatan yang dilakukan. Namun demikian masih ada adanya anggota kelompok yang tidak aktif mengikuti diskusi terutama kelompok yang anggotanya dari angkatan 2011, sehingga untuk perencanaan berikutnya perlu adanya perhatian khusus pada mahasiswa yang kurang aktif dalam diskusi dan mahasiswa yang bingung dalam melakukan pengamatan.

Kemampuan berpikir mahasiswa yang ditunjukkan pada aktivitasnya ketika proses pembelajaran berlangsung selama dua putaran mengalami kenaikan. Hal ini terlihat pada jumlah mahasiswa yang melakukan berbagai aktivitas dengan indikator kejelasan, kejujuran, kelengkapan informasi, implikasi dari solusi yang ditawarkan.

Dari hasil refleksi dapat diperoleh sejumlah pengetahuan baru atau keputusankeputusan penting guna perbaikan dan peningkatan proses pembelajaran, baik pada tataran individual, maupun manajerial. Pada tataran individual, berbagai temuan dan masukan berharga yang disampaikan pada saat diskusi dalam tahapan refleksi (check) tentunya menjadi modal bagi para dosen, baik yang bertindak sebagai dosen model maupun observer untuk mengembangkan proses pembelajaran ke arah lebih baik. Pada tataran manajerial, dengan pelibatan langsung ketua jurusan, dekan pipinan Perguruan Tinggi sebagai peserta lesson study, tentunya para pejabat tersebut akan memperoleh sejumlah masukan yang berharga bagi kepentingan pengembangan manajamen pendidikan di jurusan/fakultas/universitas secara keseluruhan.

\section{Best Practices (Praktik Baik)}

Best practice Kegiatan Lesson Study di Prodi Pendidikan Biologi Universitas Muhammadiyah Malang adalah adanya kekompakan Tim, semangat kerja dalam rangka menyelesaikan tugas dan melakukan plan do, see, dalam mata kuliah Mikroteknik dan Embriologi. Best practices Kegiatan Lesson Study di Prodi Pendidikan Biologi Universitas Muhammadiyah Malang adalah adanya kekompakan dan semangat kerja tim dosen dan mahasiswa dalam pemecahan masalah pada matakuliah Mikroteknik dan Embriologi, serta adanya perubahan paradigma pada diri dosen dari teaching menjadi learning.

\section{SIMPULAN}

Kemampuan berfikir kritis mahasiswa pendidikan biologi UMM semester enam, dengan menggunakan pembelajaran proyek pada matakuliah Mikroteknik meningkat $18 \%$ dan pembelajaran TS-TS matakuliah embriologi meningkat $15 \%$ berbasis lesson study. Best practices Kegiatan lesson study di Prodi Pendidikan Biologi Universitas Muhammadiyah Malang adalah adanya kekompakan dan semangat kerja tim dosen dan mahasiswa dalam pemecahan masalah pada matakuliah Mikroteknik dan Embriologi, serta adanya perubahan paradigma pada diri dosen dari teaching menjadi learning.

Perlu pendampingan secara intensif dan berkelanjutan, untuk melaksanakan kegiatan lesson study, guna meningkatkan kualitas pembelajaran dengan keterlibatan berbagai pihak. Kemampuan dosen dalam mengembangkan perangkat pembelajaran berkarakter, perlu ditingkatkan melalui kegiatan LS yang berkelanjutan sehingga diharapkan kualitas dosen dan Prodi semakin meningkat sehingga lebih siap 
dalam menyongsong Program Profesi Guru (PPG). Perlu dikembangkan Pelaksanaan lesson study dengan melibatkan Dosendosen lain di lingkungan Universitas Muhammadiyah Malang.

\section{DAFTAR PUSTAKA}

Corebima, A.D. 2011. Berdayakan Kemampuan Berpikir dan Kemampuan Metakognitif Selama Pembelajaran. Makalah Seminar. Malang: Jurusan Biologi FMIPA UM.

Fitri, A.S 2011. Nalar Kritis Mahasiswa, http://m.suaramerdeka.com http:// pancagarden.blogspot.com/2011/10/ normal-0-false-false-false-en-us- $x$ none_21.html (Diakses 22 Desember2013)

Hendayana, S, 2007. Lesson Study (Suatu Strategi untuk Meningkatkan Keprofesionalan Pendidik. Pengalaman IMSTEP-JICA). FPIMA UPI dan JICA. UPI Press

Ibrohim, 2011, Lesson Study untuk Meningkatkan Kompetensi Pendidik, Kualitas Pembelajaran dan Perkembangan-nya Di Indonesia, Makalah disajikan dalam Seminar Nasional Lesson Study di UNTAD Palu, 28 Oktober 2011

Karyana, N. 2013. Meningkatkan Kemampuan Berpikir Kritis Melalui Penggunaan Metode Studi Kasus. Bandung: Widyaiswara LPMP Jawa Barat.

Kemdikbud. 2013. Model Pembelajaran Berbasis Proyek (Project Based Learning). Jakarta: Kementerian Pendidikan dan Kebudayaan.

Kemendiknas, 2013, Pedoman Penulisan Makalah Lesson Study Untuk Seminar Exchange Experience, Direktorat Pembelajaran dan Kemahasiswaan, Dirjen Dikti, Kementrian Pendidikan Nasional, Jakarta.
Lie, 2002. Licenciatua en Intervencion Educativa. Unversdad Pedagogica De Duranco. http://www.upd.edu. mx/lie2002.html (Diakses 21 Desember 2013

Mahanal, S., Darmawan, E., Corebima, A.D. \& Zubaidah, S. 2009. Pengaruh Pembelajaran Project Based Learning(PjBL) pada Materi Ekosistem terhadap Sikapdan Hasil Belajar Siswa SMAN 2 Malang. Laporan Penelitian. Malang: Jurusan Biologi FMIPA Universitas Negeri Malang.

Marzano. R. J., et.al. 1994. Assessing Student Outcomes: Perfomance Assessment Using the Dimensions of Learning Model. Pittsburgh: ASCD.

Muh. Rais. 2010. Project Based Learning Inovasi Pembelajaran yang Berorientasi Soft skills disajikan dalam Seminar Nasional Pendidikan Teknologi dan Kejuruan Fakultas Teknik Universitas Negeri Surabaya 11 Desember 2010

Paul, Richard and Linda Elder. 2005. The Miniature Guide to Critical Thinking "CONCEPTS \& TOOLS". The Foundation of Critical Thinking. California

Purworini, 2006. Pembelajaran Berbasis Proyek sebagai Upaya Mengembang-kan Habit of Mind studi kasus di SMP Nasional KPS Balikpapan, SMP Nasional Balikpapan. Thomas, J.W. 2000. A Review od Research on Project-Based learning. (Online), (http://www. autodesk. com/foundation, diakses 13 November 2013).

Thomas, J.W., Margendoller, J.R., \& Michaelson, A. 1999. Project-Based Learning: A. Handbook for Middle and High School Teachers. (Online). 
(http://www.bgsu.edu/organizations/ ctl/proj.html., Diakses tanggal 25 November 2013).

Supriatna, Asep, 2012, Lesson Study, makalah disampaikan pada sosialisasi Lesson Study pada Penerima Hibah LPTK Tahun ke-2, JPMIPA-FKIP Tahun 2012, di Universitas Muhammadiyah Malang, 